\title{
Pemodelan dan Simulasi Video Streaming pada Jaringan 802.11 a dan 802.11b dengan Menggunakan Network Simulator 2 (NS2)
}

\author{
Dedi Hary Saputra ${ }^{1}$, Helmy Fitriawan ${ }^{2}$, Herlinawati ${ }^{3}$ \\ ${ }^{1,2,3}$ Jurusan Teknik Elektro Fakultas Teknik Universitas Lampung
}

Intisari--- Streaming video merupakan sebuah teknologi yang mampu mengirim file audio dan video dari sebuah server melalui suatu jaringan dalam ukuran yang lebih kecil. Efisiensi dan manajemen dalam penggunaan jaringan wireless menjadi hal yang penting dalam membangun suatu jaringan streaming video. Besarnya bandwith, serta kecepatan pengiriman data pada wireless yang akan digunakan dalam streaming video akan mempengaruhi kualitas hasil streaming video. Penelitian dilakukan menggunakan perangkat lunak Network Simulator versi 2 (NS2) dengan menggunakan cygwin agar dapat berjalan pada sistem operasi Windows. Pemodelan dan simulasi didasarkan pada parameter spesifikasi wireless cisco aironet 1130AG dan mengacu kepada standar IEEE 802.11a dan IEEE 802.11b. Kinerja jaringan pada streaming video menggunakan protokol IEEE 802.11a dan 802.11b dengan melakukan beberapa variasi keadaan dan membandingkan kualitas kedua protokol. Hasil menunjukan bahwa pada protokol 802.11a menghasilkan kualitas yang lebih baik dalam penanganan layanan streaming video dibandingkan protokol 802.11b. Pada simulasi protokol 802.11a memberikan tingkat performansi nilai delay, paket loss, yang lebih kecil dibandingkan dengan simulasi menggunakan protokol $\mathbf{8 0 2 . 1 1 b}$.

Kata kunci--- Streaming video, IEEE 802.11a, IEEE 802.11b, Network Simulator, Pemodelan dan Simulasi.

Abstract--- Video streaming is a technology that is capable of sending audio and video files from a server via a network in a smaller size. Efficiency in the use and management of wireless networks have become important factors in building a network of streaming video. The amount of bandwidth, as well as the speed of data transmission in wireless video streaming will be used in will affect the quality of streaming video. The study was conducted using the software Network Simulator version 2 (NS2) using cygwin to run on the Windows operating system. Modeling and simulation based on the parameters of the Cisco Aironet $1130 \mathrm{AG}$ wireless specifications and adhere to standards IEEE 802.11a and IEEE 802.11b. Network performance on streaming video using the IEEE $802.11 \mathrm{a}$ and $802.11 \mathrm{~b}$ protocol by doing some variation of circumstances and compare the quality of the two protocols. The results showed that the 802.11a protocol produces better quality video streaming services in handling than the $802.11 \mathrm{~b}$ protocol. In the 802.11 a protocol simulations provide the level of performance value delay, packet loss, which is smaller than the simulation using the $802.11 \mathrm{~b}$ protocol.

Keywords--- Streaming video, IEEE 802.11a, IEEE 802.11b, Network Simulator, Pemodelan dan Simulasi.

\section{PENDAHULUAN}

Penggunaan jaringan wireless sekarang ini sudah semakin banyak, baik digunakan untuk kepentingan pribadi, bisnis maupun penelitian. Salah satu aplikasi yang dapat digunakan dalam jaringan wireless adalah streaming video. Streaming video merupakan sebuah teknologi yang mampu mengirim file video dan audio dari sebuah server melalui suatu jaringan dengan ukuran yang lebih kecil. Efisiensi dan manajemen dalam penggunaan jaringan wireless menjadi hal yang penting dalam membangun suatu jaringan streaming video. Besarnya bandwith, serta kecepatan pengiriman data pada jaringan wireless yang akan digunakan dalam streaming video akan mempengaruhi kualitas hasil streaming video. Untuk itu diperlukan penelitian berupa pengukuran trafik jaringan, pemodelan dan simulasi dengan perhitungan beberapa parameter

Quality of Service (QoS). Jaringan yang digunakan adalah wireless dengan standar 802.11a dan 802.11 b yang tipikalnya bekerja di bandwidth 2,4 GHz (802.11b) atau $5 \mathrm{GHz}$ (802.11a) serta data rate maksimum 11 Mbps (802.11b) dan 54 Mbps (802.11a). Pemodelan dan simulasi merupakan salah satu bentuk gambaran yang dapat digunakan untuk melihat kinerja dari jaringan wireless untuk streaming video.

\section{TINJAUAN PUSTAKA}

\section{A. Streaming Video}

Streaming video merupakan sebuah teknologi yang memungkinkan pentransmisian data berupa audio dan video. Pengkodean dari video atau citra 
bergerak yang bisa digunakan adalah MPEG (Moving Picture Expert Group). Adapun beberapa jenis estándar yang digunakan diantaranya : MPEG 1, MPEG 2 , MPEG 3 dan MPEG 4.[1] Adapun beberapa komponen yang digunakan dalam streaming video adalah : video, Encoder dan Decoder, Receiver.

\section{B. Wireless}

Wireless merupakan teknologi yang menghubungkan dua perangkat atau lebih untuk berkomunikasi mengakses suatu aplikasi pada perangkat lain dengan menggunakan gelombang radio atau sejenisnya Ada tiga standar yang biasanya dimplementasikan diantaranya $802.11 \mathrm{a}$, 802.11 b dan 802.11g.[2]

\section{Protokol}

Protokol adalah sebuah aturan yang mendifinisakan beberapa fungsi yang ada dalam sebuah jaringan. Secara umum fungsi protocol adalah untuk menghubungkan sisi pengirim dan penerima dalam berkomunikasi dalam berkomunikasi serta bertukar informasi agar dapat berjalan dengan baikdan benar dengan kehandalan yang tinggi.[3]

\section{Network Simulator 2 (NS2)}

Network simulator 2 merupakan sebuah perangkat lunak yang digunakan untuk melakukan simulasi networking, mulai dari LAN, WLAN dan WIMAX. Simulator NS 2 dijalankan dengan menggunakan dua bahasa pemrograman, yaitu

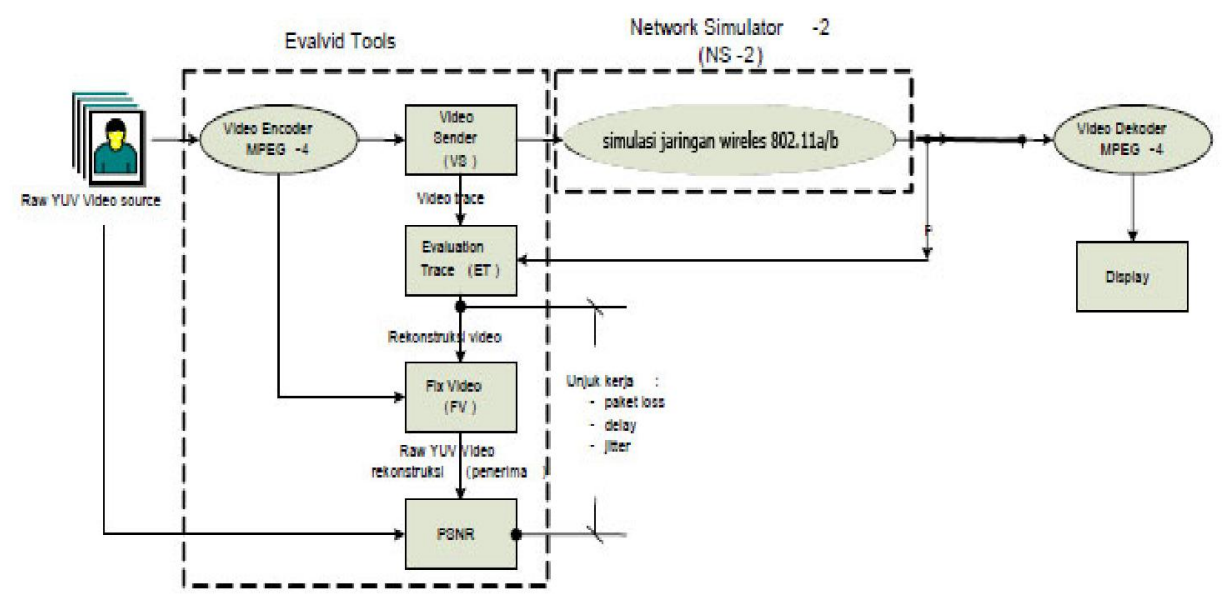

$\mathrm{C}++$ dan Otcl. $\mathrm{C}++$ berfungsi dalam menangani mekanisme internal pada simulasi dengan NS2. OTcl menangani interaksi langsung antara pengguna dengan simulator serta menangani antara objek-objek OTcl lainnya. $\mathrm{C}++$ dan OTcl saling terhubung dengan menggunakan komponen TclCl. Variabel-variabel domain OTcl dipetakan dengan mengunakan $\mathrm{C}++.[4]$

\section{E. Evalvid}

Evalvid merupakan sebuah perangkat lunak yang dapat digunakan untuk menganalisa kualitas video yang ditransmisikan baik secara nyata maupun simulasi pada sebuah jaringan, Evalvid dilengkapi dengan paket/frame loss, paket frame jitter, PSNR, dan MOS metric untuk tujuan assessment [5-6]

\section{METODE PENELITIAN}

Dalam penelitian ini dilakukan pengujian terhadap perfomansi dari jaringan wireless untuk streaming video. Pemodelan dan simulasi dibagi dalam dua tahapan. Pada simulasi pertama adalah sebuah user hanya mengakses sebuah video dari sebuah server. Sedangkan Untuk simulasi kedua user tidak hanya mengkases video, tetapi melakukan aktivitas lain( background traffic). Adapun bentuk variasi lain dalam penelitian adalah jumlah frame video jumlah user, dan background traffic. Semua tahapan tersebut dilakukan dengan mengunakan wireless $802.11 \mathrm{a}$ dan $802.11 \mathrm{~b}$ secara bergantian.

Gambar 1: Proses video streaming pada jaringan 802.11[7]

Seperti pada Gambar 1 di atas implementasi pada simulasi video streaming dimulasi dari raw video source. File video tersebut disimpan dalam bentuk YUV. File YUV tersebut kemudian di encoder, yaitu menggunakan tools
Mpeg4encoder.exe. Hasil file tersebut kemudian diextrak untuk menghasilkan trace file dengan menggunakan MP4.exe. Hasil file trace tersebut kemudian disematkan kedalam program.$T c l$. Setalah itu dilakukan eksekusi dengan 
menggunakan program NS2. Hasil dari eksekusi tersebut berupa file $r d$ dan $s d$. File $r d$ dan $s d$ tersebut kemudian dengan bantuan tools Et.exe digunakan untuk menghasilkan paket loss, delay dan jitter. Kemudian untuk menganalisa kualitas hasil video dari eksekusi dengan NS 2, pertama tama file video di decoder kembali dengan menggunakan Mpeg4decoder.exe. Dengan bantuan myfix.exe memperbaiki urutan video yang kemungkinan terdapat kesalahan akibat hasil decoder taduigunakan psnr.exe untuk menghiitung PSNR dari video hasil pengujian tersebut

\section{HASIL DAN PEMBAHASAN}

A. Perbandingan End to End delay pada protocol 802.11 a dan $802.11 \mathrm{~b}$

1. Perbandingan End to end delay dua receiver

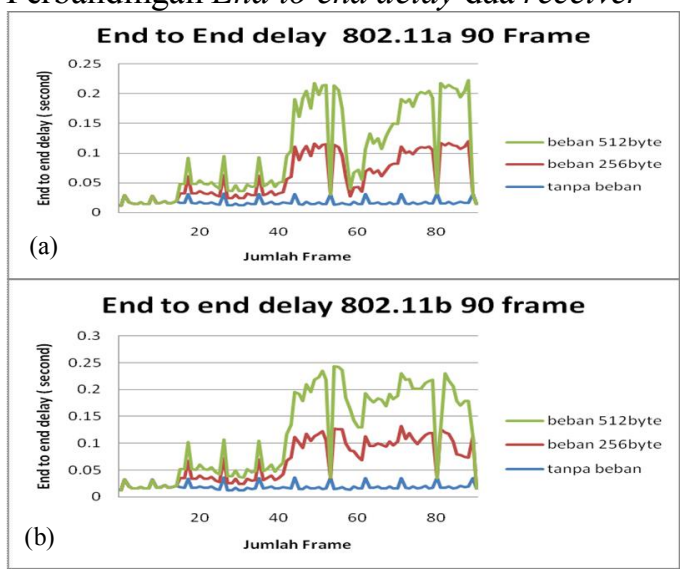

Gambar 2: Grafik perbandingan End to End delay antara protocol 802.11a dan 802.11b 90 frame terhadap variasi jumlah paket beban traffic : (a) 802.11a dan (b) 802.11 b

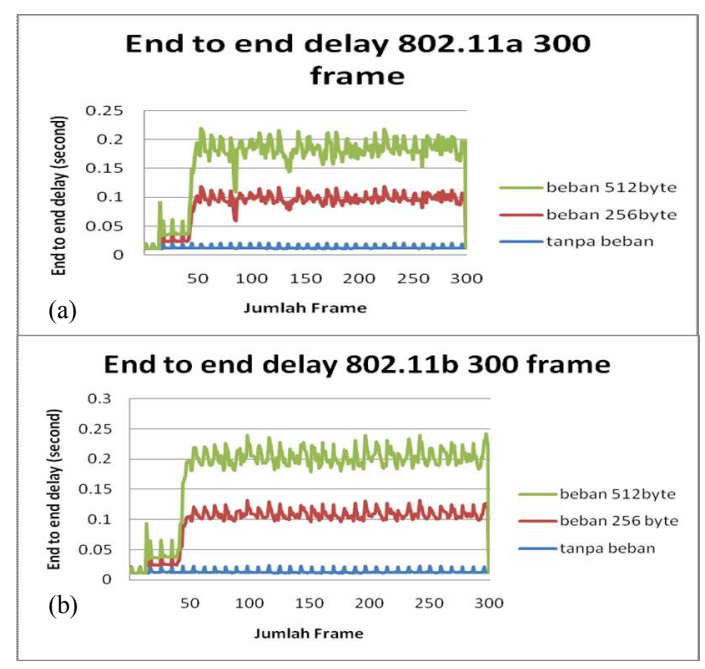

Gambar 3 : Grafik perbandingan End to End delay antara protocol 802.11a dan 802.11b 300 frame terhadap variasi jumlah paket beban traffic : (a) 802.11a dan (b) $802.11 \mathrm{~b}$

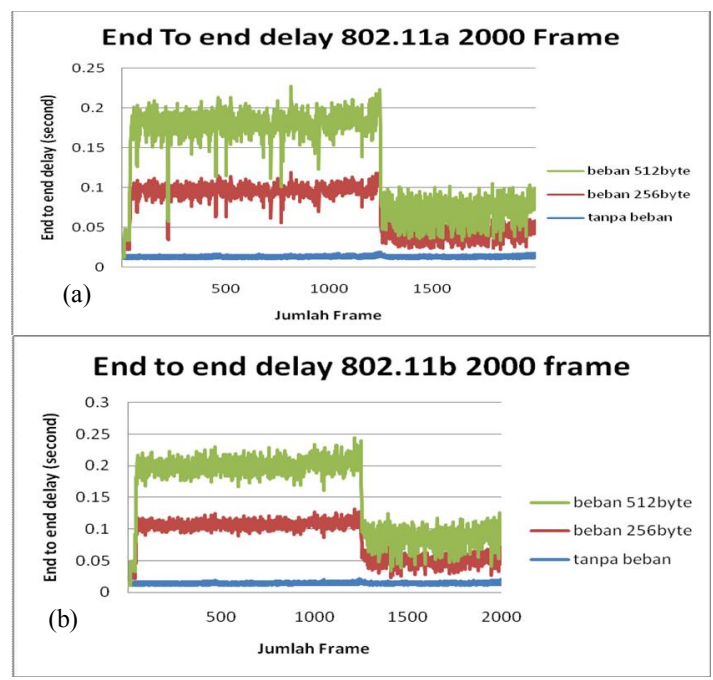

Gambar 4 : Grafik perbandingan End to End delay antara protocol 802.11a dan 802.11b 2000 frame terhadap variasi jumlah paket beban traffic : (a) 802.11a dan (b) 802.11b

Pada Gambar 2 menggambarkan perbandingan end to end delay dengan jumlah frame 90. Dari kedua grafik terlihat, bahwa nilai delay yang dihashilkan pada protokol 802.11a lebih kecil bila dibandingkan dengan protokol 802.11b. Pada kedua protokol terlihat bahwa penambahan beban dalam jaringan, meningkatkan nilai end to end delay yang dihasilkan.

Pada Gambar 3 menggambarkan perbandingan end to end delay dengan jumlah frame 300 . Pada grafik terlihat pada saat pemberian beban nilai end to end delay yang dihasilkan pada protokol 802.11 a berkisar diantara 0.21 second. Sedangkan pada protokol $802.11 \mathrm{~b}$ nilainya hampir menyentuh 0.25 second. Dari grafik di atas terlihat bahwa pada saat penambahan beban nilai end to end delay sama-sama mengalami peningkatan, namun nilai delay dihasilkan pada protokol 802.11a lebih baik bila dibandingkan pada protokol $802.11 \mathrm{~b}$ hal ini menyatakan bahwa protokol 802.11a lebih baik dalam mengatasi delay dikarekan nilai bandwith yang lebih besar bila dibandingkan dengan protokol 802.11b.

Pada Gambar 4 menggambarkan perbandingan end to end delay dengan jumlah frame 2000. Pada grafik menggambarkan penambahan beban pada jaringan akan meningkatkan nilai delay. Hal tersebut berlaku untuk kedua protokol. Terlihat pada protokol 802.11a tanpa beban nilai end to end delay adalah 0.02 second, ketika diberikan beban 256 byte nilainya meningkat menjadi 0.12 second dan pada saat beban ditingkatkan menjadi 512 byte nilai end to end delay semakin meningkat, yaitu 0.23 second. Peningkatan nilai end to end delay pada saat peningkatan beban pada jaringan juga berlaku pada protokol 802.11b. 
Pada 802.11b 2000 frame tanpa beban nilai end to end delay yang dihasilkan adalah 0.02 second. Pada saat beban dinaikkan menjadi beban 256 byte dan 512 byte, nilai end to end delay adalah 0.12 second dan 0.25 second. Ini menunjukan bahwa nilai end to end delay berbanding lurus dengan nilai beban yang terdapat dalam jaringan.

Dari Gambar 2,3, dan 4 dapat dilihat juga perbandingan protokol terhadap jumlah frame terlihat bahwa baik pada protokol 802.11a dan $802.11 \mathrm{~b}$ keduanya tidak menghasilkan perbedaan yang begitu mencolok pada saat jumlah frame bertambah.

\section{Perbandingan End to end delay tiga receiver}

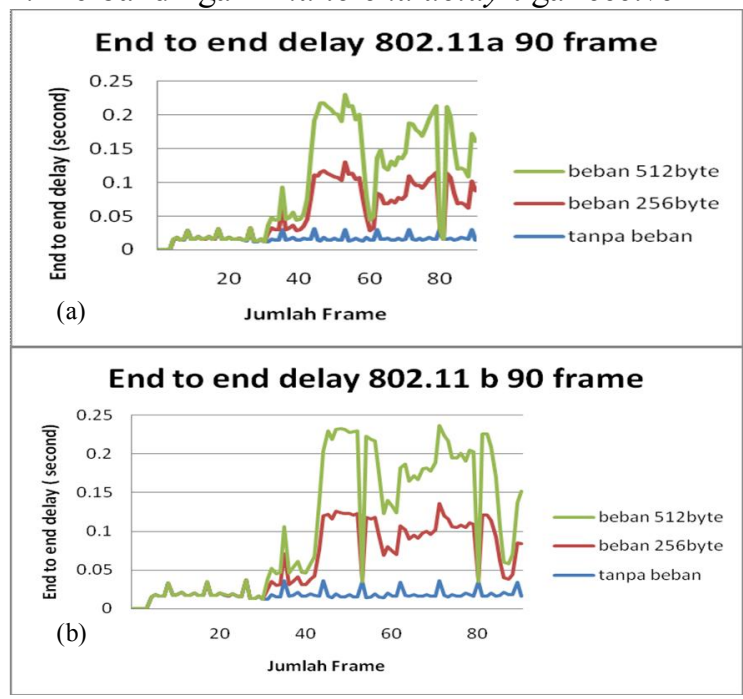

Gambar 5 : Grafik perbandingan End to End delay antara protocol 802.11a dan 802.11b 90 frame terhadap variasi jumlah paket beban traffic : (a) 802.11a dan (b) $802.11 \mathrm{~b}$

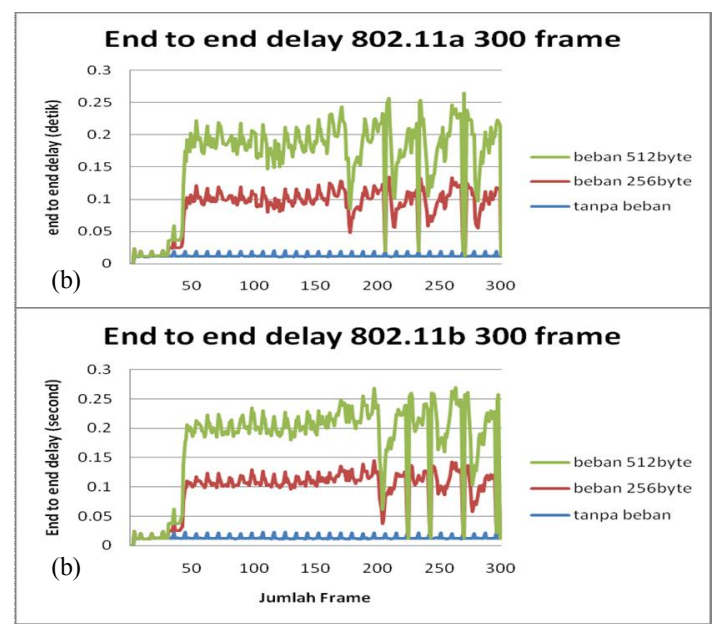

Gambar 6 : Grafik perbandingan End to End delay antara protocol 802.11a dan 802.11b 300 frame terhadap variasi jumlah paket beban traffic : (a) $802.11 \mathrm{a}$ dan (b) $802.11 \mathrm{~b}$

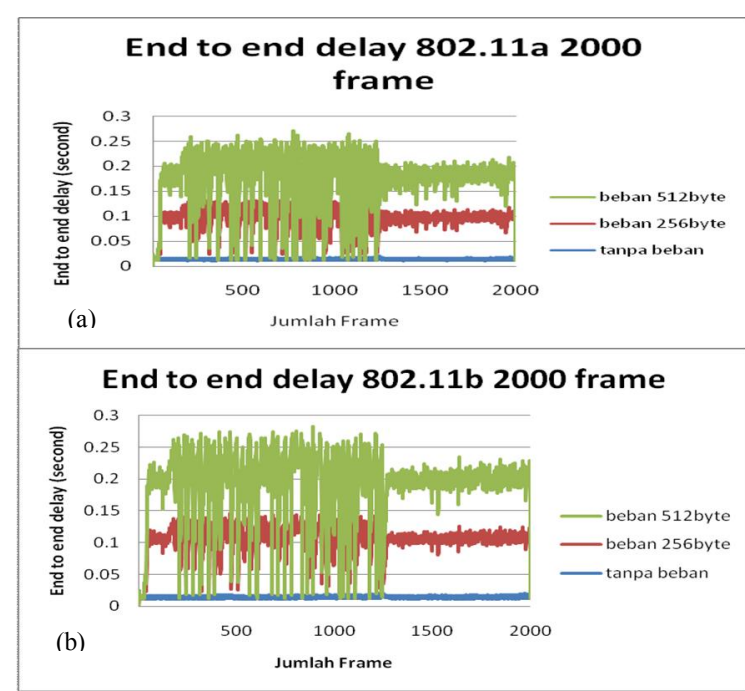

Gambar 7 : Grafik perbandingan End to End delay antara protocol 802.11a dan 802.11b 2000 frame terhadap variasi jumlah paket beban traffic : (a) $802.11 \mathrm{a}$ dan (b) $802.11 \mathrm{~b}$

Gambar 5, 6 dan 7 merupakan grafik perbandingan end to end delay antara protokol 802.11a dengan protokol 802.11b. Pada gambar terlihat baik pada protokol 802.11a maupun $802.11 \mathrm{~b}$ mengindikasikan bahwa penambahan jumlah pada kedua protokol mempengaruhi jumlah end to end delay yang dihasilkan. Pada dasarnya baik protokol 802.11 a maupun $802.11 \mathrm{~b}$ mengalami peningkatan delay yang disebabkan oleh peningkatan jumlah data yang dihasilkan. Peningkatan delay juga terjadi pada saat penambahan jumlah reciever. Baik pada protokol 802.11a maupun 802.11b keduanya mengalami peningkatan delay. Yang membedakan antara keduanya hanya end to end delay pada protokol 802.11b lebih besar dibandingkan 802.11a, ini menjelaskan bahwa kinerja protokol 802.11a dalam hal end to end delay lebih baik.

\section{B. Perbandingan paket loss pada protocol 802.11 a dan $802.11 \mathrm{~b}$ \\ Pada protokol 802.11a maupun 802.11b} mengindikasikan bahwa penambahan jumlah beban dan reciever pada kedua protokol mempengaruhi jumlah loss yang dihasilkan. Pada dasarnya baik protokol 802.11a maupun $802.11 \mathrm{~b}$ mengalami peningkatan loss yang disebabkan oleh peningkatan jumlah data yang dihasilkan. Yang membedakan antara keduanya adalah nilai paket loss pada protokol 802.11b lebih besar dibandingkan 802.11a. Hal ini dikarenakan kesediaan bandwith pada protokol 802.11a lebih besar dibandingkan bandwith pada 802.11b. Sehingga data yang hilang pada jaringan 802.11a lebih sedikit bila dibandingkan dengan protokol 802.11 b. Ini juga menjelaskan bahwa kinerja 
protokol 802.11a dalam hal loss frame lebih baik bila dibandingkan protokol $802.11 \mathrm{~b}$

\section{Perbandingan PSNR pada protocol 802.11a dan $802.11 \mathrm{~b}$}

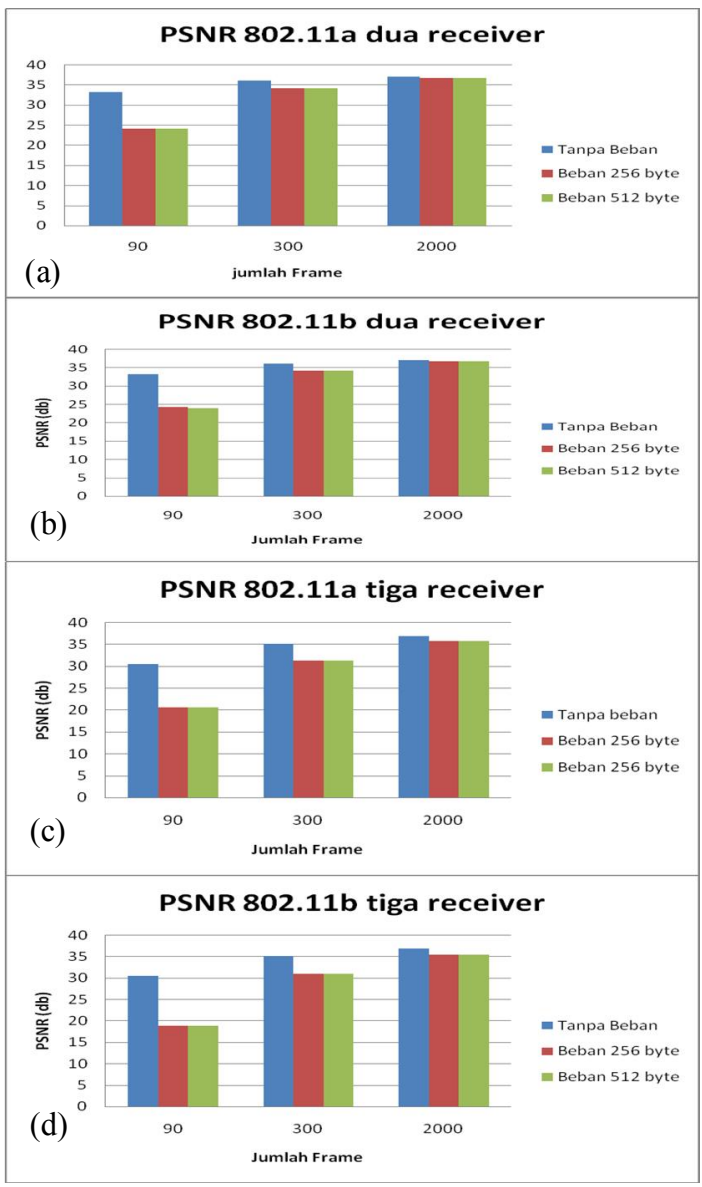

Gambar 8 : Grafik perbandingan PSNR dengan variasi jumlah receiver antara protocol 802.11 a: (a) dua receiver, (c) tiga receiver dengan protocol $802.11 \mathrm{~b}$ : (b) dua receiver, $(\mathrm{d})$ tiga receiver

Dari Gambar 8 terlihat bahwa pada kedua protokol peningkatan jumlah beban dalam jaringan mengindikasikan penurunan nilai PSNR yang dihasilkan. Penurunan juga dihasilkan dari peningkatan jumlah frame yang digunakan dalam video yang ditransmisikan. Jumlah reciver pengakses video streaming juga berpengaruh terhadap nilai PSNR yang di dapatkan. Semakin banyak reciver maka data yang dibutuhkan semakin besar sehingga tumbukan pada proses transmisi lebih mungkin terjadi yang dapat menyebabkan loss frame pada video yang dikirimkan. Secara keseluruhan, nilai PSNR yang dihasilkan protokol 802.11a lebih besar dibandingkan dengan PSNR yang dihasilkan dari protokol 802.11b. Hal ini dikarenakan penanganan kebutuhan bandwith yang besar untuk proses pengiriman video streaming dapat ditangani lebih baik oleh protokol 802.11a dibandingkan dengan $802.11 \mathrm{~b}$

\section{KESIMPULAN}

Dari pemodelan dan simulasi jaringan streaming video baik pada wireless 802.11a dan wireless $802.11 \mathrm{~b}$, didapat kesimpulan sebagai berikut:

1. Nilai end to end delay pada 802.11a saat tanpa beban adalah 0.02 second, pada saat beban 256 byte adalah 0,12 second, pada saat beban 512 byte adalah 0.22 second. Sedangkan pada $802.11 \mathrm{~b}$ nilai end to end delay pada saat tanpa beban adalah 0.03 second, pada saat beban 256 byte adalah 0.14 second, beban 512 byte adalah 0.23 second. Dari hasil ini terlihat bahwa semakin besar beban paket yang diberikan baik pada protokol 802.11 a maupun $802.11 \mathrm{~b}$ maka nilai end to end delay yang dihasilkan akan semakin besar.

2. Baik pada protokol 802.11a maupun $802.11 \mathrm{~b}$ menunjukkan peningkatan jumlah frame dan jumlah receiver, berpengaruh terhadap nilai paket loss yang dihasilkan. Semakin besar jumlah frame dan jumlah receiver, maka nilai paket loss yang dihasilkan juga semakin besar.

3. Nilai PSNR 802.11a pada frame 90 tanpa beban, beban 256 byte, dan 512 byte dengan tiga receiver berturut-turut adalah $30.55 \mathrm{db}$, $20.65 \mathrm{db}$, dan $20.65 \mathrm{db}$. Nilai PSNR $802.11 \mathrm{~b}$ pada frame 90 tanpa beban, beban 256 byte, dan 512 byte dengan tiga receiver berturutturut adalah $30.55 \mathrm{db}, 18.84 \mathrm{db}$, dan $18.84 \mathrm{db}$. Dari hasil diatas menunjukan bahwa semakin besar beban yang diberikan, maka nilai PSNR yang dihasilkan akan semakin kecil.

4. Dari perbandingan nilai End to end delay, paket loss, dan PSNR pada jaringan nirkabel 802.11a memiliki nilai yang lebih baik bila dibandingkan dengan protokol $802.11 \mathrm{~b}$. Hal ini menunjukan $Q o S$ pada protokol 802.11a lebih baik bila dibandingkan daripada protokol $802.11 \mathrm{~b}$ dalam layanan video streaming

\section{REFERENSI}

[1] http://id.wikipedia.org/wiki/MPEG (diakses 12 Januari 2013)

[2] Purbo W. Ono. Wireless di dunia berkembang.

[3] Sofana, Iwan. Cisco CCNA jaringan komputer

[4] Network Simulator, www.isi.edu/nsnam/ns/ (diakses 10 Mei 2012)

[5] EvalVid - A Video Quality Evaluation Toolset" http://www.tkn.tuberlin.de/research/evalvid/ 
http://140.116.164.80/ jhlin5/ns2/Prepare\%2

0work $\% 20$ for $\% 20$ multimedia $\% 20$ experimen

t.htm (diakses 15 Oktober 2012)

[6] EvalVid,

http://hpds.ee.ncku.edu.tw/ smallko/ns2/Eva lvid_in_NS2.htm (diakses 15 oktober 2012)

[7] Jirka Klaue, Berthold Rathke and Adam Wolisz," Evalvid-A Framework for Video Transmission and Quality Evaluation”, Proc. of the $13^{\text {th }}$ International Conference On Modelling Techniques dan Tools for computer performance, Urbana, Illinois, USA, September 2003 